International Journal of Environment, Agriculture and Biotechnology
Vol-6, Issue-2; Mar-Apr, 2021

\title{
Development and Quality Evaluation of Ragi Supplemented Cupcakes
}

\author{
Kavita Mane, Mayur Kadam
}

Department of Food Process and Product Engineering, MITSoFT, Pune, India

Received: 09 Nov 2020; Received in revised form: 11 Feb 2021; Accepted: 07 Mar 2021; Available online: 03 Apr 2021

(C)2021 The Author(s). Published by Infogain Publication. This is an open access article under the CC BY license

(https://creativecommons.org/licenses/by/4.0/).

\begin{abstract}
India consumes large amount of the bakery products and cupcake is one of them which is being largely consumed by children. The improvement in living standard and awareness towards health food have diverted the people mindset of food consumption that generated immense scope in value addition of bakery products so present investigation was undertaken to prepare nutritionally rich cupcakes by partial replacement of maida with ragi flour which is rich in calcium, iron and fibers. Cupcakes were prepared with different proportions (100:00, 70:30, 60:40 and 50:50) of maida and ragi and proven acceptability of ragi supplemented cupcakes (60:40 proportions of maida and ragi) with overall acceptability of 7.5 that justified mineral content as $166.34 \mathrm{mg} / 100 \mathrm{~g}$ calcium and $1.58 \mathrm{mg} / 100 \mathrm{~g}$ iron.
\end{abstract}

Keywords-Bakery products, cupcakes, maida, ragi, sensory evaluation.

\section{INTRODUCTION}

Bakery products are gaining much importance due to increasing demand of convenience food and so becoming popular among children as well as adults. Wheat is the most prevalent element in bakery products like bread, biscuits and cakes. Recently improvement in living standard and awareness towards health food have diverted the people mindset of food consumption that generated immense scope in value addition of bakery products like bread, biscuits, cakes etc. Cupcakes are specialty small cakes that are popular among home and commercial bakers. Initially, cupcakes were popular in western countries only and were considered as rich men's food. However with rejuvenation of society they are acquiring importance all over the world. They are desired for brunch and/or supplementary meals and are on the other hand served with tea. Several varieties with different flavors such as strawberry, chocolate, vanilla, butterscotch etc. of cupcakes are available all over the world.

Ragi (Eleusine Coracana L.), also known as finger millet is popular in India mostly consumed without de-hulling [1]. It is vibrant millet grown in several states of India and Africa and established as a principal food for a huge section of the residents in these countries [2]. Ragi is distinguished cereal rich in protein, fiber and minerals like iron, calcium and phosphorus along with essential amino acids and vitamins $\mathrm{A}$ and $\mathrm{B}[1,3]$. Thus ragi has proven its nutritional goodness as a functional ingredient in development of food for children, pregnant women, sick and old age people. Being a major source of calcium, dietary fibers and polyphenol, it is also acknowledged for health benefit potential, such as anti-diabetic, antitumerogenic, atherosclerogenic effects, antioxidant and antimicrobial properties. The deliberate assimilation rate of ragi proficiently supports to regulate blood glucose levels in diabetic patients $[2,4]$. The ragi millet grains are versatile ingredient that opens many doors for health food development inclusive with appropriate processing techniques [5]. The present study was undertaken to develop the process technology for ragi millet supplemented cupcakes with recipe standardization and nutritional characterization.

\section{METHODOLOGY}

\section{Materials}

Wheat flour (Maida), ragi and various other ingredients like cocoa powder, milk powder, baking powder, baking 
soda, chocolate essence, margarine, sugar, and eggs were procured from the local market for preparation of the cupcakes.

\section{Packaging Material}

Paper cups were used as primary packaging material, polypropylene trays for holding the cups and the HDPE bags were used as secondary packaging material.

\section{Processing of ragi cupcakes}

Good quality raw material were received from local market and preliminary cleaning operations were undertaken. Ragi was subjected to grinding to obtain fine texture. All dry powder ingredients were sieved properly to eliminate foreign particles and course material followed by weighing as per the formulation shown in Table 1. Beating of margarine with sugar was carried out to prepare cream and batter was prepared by mixing of all dry ingredients to it. Paper cups were placed in moulds and weighed quantity of batter was filled in cups with help of cone filler. Thereafter moulds were kept in preheated baking oven $\left(140^{\circ} \mathrm{C}\right.$ for $\left.15 \mathrm{~min}\right)$ for baking which was followed by cooling of cupcakes at room temperature. Cooled cupcakes were packed in the polypropylene trays and covered by HDPE which were then sealed and labeled.

\section{Quality analysis}

Maida, ragi flour and prepared cupcakes were analyzed for nutritional and organoleptic characteristics using standard methods. Data generated was analyzed for statistical significance by ANOVA using 5\% level of significance.

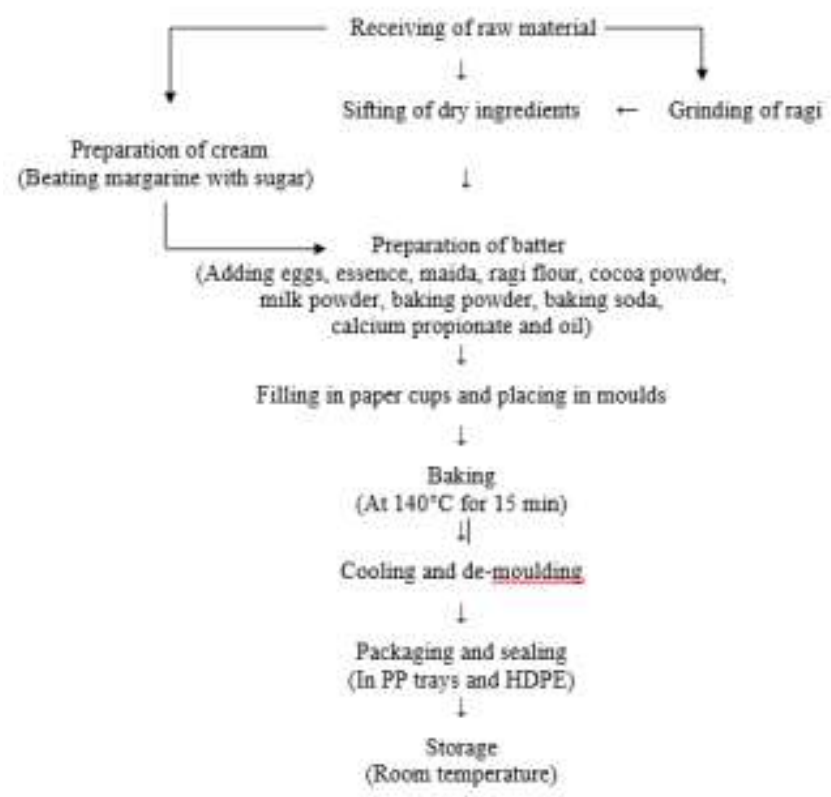

Fig.1: Process flowchart for preparation of ragi cupcakes
Table 1: Formulation of ragi cupcakes

\begin{tabular}{|l|c|c|c|c|}
\hline Ingredient & $\mathbf{S}_{\mathbf{0}}$ & $\mathbf{S}_{\mathbf{1}}$ & $\mathbf{S}_{\mathbf{2}}$ & $\mathbf{S}_{\mathbf{3}}$ \\
\hline Maida (g) & 100 & 70 & 60 & 50 \\
\hline Ragi flour(g) & 0 & 30 & 40 & 50 \\
\hline Sugar(g) & 120 & 120 & 120 & 120 \\
\hline Margarine(g) & 100 & 100 & 100 & 100 \\
\hline Eggs(No.) & 4 & 4 & 4 & 4 \\
\hline Oil(ml) & 25 & 25 & 25 & 25 \\
\hline Cocoa Powder(g) & 5 & 5 & 5 & 5 \\
\hline Milk Powder(g) & 5 & 5 & 5 & 5 \\
\hline $\begin{array}{l}\text { Baking Powder(g) } \\
\text { Baking Soda(g) }\end{array}$ & 2 & 2 & 2 & 2 \\
\hline $\begin{array}{l}\text { Chocolate } \\
\text { Essence(ml) }\end{array}$ & 2 & 2 & 2 & 2 \\
\hline $\begin{array}{l}\text { Calcium } \\
\text { Propionate(g) }\end{array}$ & 0.5 & 0.5 & 0.5 & 0.5 \\
\hline
\end{tabular}

\section{Methods of analyzing of nutrients}

Moisture content was determined by standard oven method [6]. Values of crude ash, crude fibers, crude fat and proteins were determined by using muffle furnace, Fibrotron, Soxhlet apparatus and Micro-Kjeldahl method, respectively. Carbohydrate contents were determined by calculation method $[7,8]$.

\section{Physical parameters}

Ten different samples of cupcakes were analyzed for size (vernier caliper) and weight (weighing balance) and average values calculated.

\section{Sensory Evaluation}

Sensory evaluation of different organoleptic properties viz color and appearance, texture, taste, flavor and overall acceptability were carried out by a semi-trained panel of judges using 9 point hedonic scale [9]. The average score was calculated for individual organoleptic properties and presented graphically.

\section{RESULTS AND DISCUSSIONS}

\section{Proximate composition of maida and ragi flour}

The proximate composition of maida and ragi flour were determined and tabulated in Table 2. 
Table 2 Proximate composition of raw material

\begin{tabular}{|l|c|c|}
\hline \multicolumn{1}{|c|}{$\begin{array}{c}\text { Proximate } \\
\text { Composition }\end{array}$} & Maida & Ragi flour \\
\hline Moisture (\%) & $12.9 \pm 0.63$ & $12.57 \pm 0.24$ \\
\hline Ash (\%) & $0.86 \pm 0.03$ & $1.41 \pm 0.08$ \\
\hline Crude fiber & $0.35 \pm 0.04$ & $3.51 \pm 0.06$ \\
\hline Fat (\%) & $1.61 \pm 0.10$ & $1.08 \pm 0.02$ \\
\hline Protein (\%) & $9.96 \pm 0.29$ & $7.45 \pm 0.12$ \\
\hline $\begin{array}{l}\text { Carbohydrate } \\
(\%)\end{array}$ & $74.44 \pm 0.07$ & $75.04 \pm 0.17$ \\
\hline
\end{tabular}

\section{Nutritional composition of ragi supplemented cupcakes}

Data on nutritional composition of ragi cupcakes depicted in Table 3 indicates the effect of ragi supplementation on nutritional composition of cupcakes. Moisture content was found maximum $(24.37 \%)$ in control cupcake containing no ragi in it whereas minimum $(23.31 \%)$ in cupcakes with 60:40 proportions of Maida: Ragi. Ash content in ragi cupcakes were found in the range between 1.23 to $2.31 \%$. It was found maximum $(2.31 \%)$ in the cupcakes with 60:40 proportions of maida and ragi whereas minimum $(1.23 \%)$ in control sample. Crude fiber content were found more $(0.63-1.11 \%)$ in ragi supplemented cupcakes as compared to cupcakes without ragi $(0.32 \%)$. Fat and protein contents in the cupcakes were decreased with increase in ragi flour. Fat content was found maximum $(23.13 \%)$ in control cupcakes whereas minimum $(20.02 \%)$ in cupcakes with 60:40 proportions of maida and ragi. The significant effect of ragi supplementation was observed in protein content of cupcakes. It was found maximum $(7.73 \%)$ in cupcakes without ragi whereas minimum $(7.03 \%)$ in the cupcakes with $60: 40$ proportion of maida and ragi. Carbohydrate content in the ragi cupcakes was found in the range from 43.23 to $46.22 \%$. Maximum carbohydrate content $(46.22 \%)$ was found in in the cupcakes with $60: 40$ proportion of maida and ragi whereas minimum (43.23) in cupcakes without ragi.

Calcium content in ragi cupcakes were found in the range from 140.11 to $168.45 \mathrm{mg} / 100 \mathrm{~g}$ of cupcakes. The significant increase in calcium content was observed with increase in ragi flour supplementation in cupcakes. It was found maximum $(168.45 \mathrm{mg} / 100 \mathrm{~g})$ in the cupcakes with $60: 40$ proportions of maida and ragi whereas minimum $(140.11 \mathrm{mg} / 100 \mathrm{~g})$ in cupcakes without ragi. The significant effect of ragi flour supplementation was observed on iron content of cupcakes It was found maximum $(1.61 \mathrm{mg} / 100 \mathrm{~g})$ in the cupcakes with 50:50 proportions of maida and ragi whereas minimum $(1.17 \mathrm{mg} / 100 \mathrm{~g})$ in control sample.
Increase in minerals content of halwa mix with increased level of ragi might be due to presence of more minerals content in ragi [10].

Table 3: Nutrient composition of ragi cupcake

\begin{tabular}{|c|c|c|c|c|c|c|c|c|}
\hline Samp & Moistu & Ash & Cru & Fat & Protei & $\begin{array}{l}\text { Carbo } \\
\text { hydra }\end{array}$ & $\begin{array}{l}\text { Calcium } \\
(\mathrm{mg} / 100\end{array}$ & $\begin{array}{c}\text { Iron } \\
(\mathrm{mg} / 100\end{array}$ \\
\hline le & & & $\begin{array}{c}\text { fiber } \\
(\%)\end{array}$ & & & $\begin{array}{c}\text { tes } \\
(\%)\end{array}$ & g) & g) \\
\hline $\mathbf{S}_{\mathbf{0}}$ & 24.37 & 1.23 & 0.32 & $\begin{array}{c}23.1 \\
2\end{array}$ & 7.73 & 43.23 & 140.11 & 1.17 \\
\hline $\mathbf{S}_{1}$ & 24.11 & 1.56 & 0.63 & 22.4 & 7.41 & 43.89 & 162.61 & 1.47 \\
\hline $\mathbf{S}_{2}$ & 23.86 & 2.15 & 0.87 & $\begin{array}{c}21.2 \\
5\end{array}$ & 7.16 & 44.71 & 166.34 & 1.58 \\
\hline $\mathbf{S}_{\mathbf{3}}$ & 23.31 & 2.31 & 1.11 & $\begin{array}{c}20.0 \\
2\end{array}$ & 7.03 & 46.22 & 168.45 & 1.61 \\
\hline $\begin{array}{l}\text { SE } \\
( \pm)\end{array}$ & 0.23 & 0.25 & 0.17 & 0.68 & 0.15 & 0.64 & 6.53 & 0.10 \\
\hline $\begin{array}{c}\text { CD } \\
(5 \%)\end{array}$ & 0.55 & 0.61 & 0.41 & 1.64 & 0.37 & 1.56 & 15.83 & 0.24 \\
\hline
\end{tabular}

\section{Physical properties}

Physical properties of cupcake are shown in Table 4. The size of cupcake was found between 7.26 and $7.33 \mathrm{~cm}$. The weight of cupcake was found in the range from 102.29 to $105.60 \mathrm{~g}$.

Table 4 Physical properties of cupcake

\begin{tabular}{|c|c|c|}
\hline Sample & Size (cm) & Weight $(\mathbf{g})$ \\
\hline $\mathbf{S}_{\mathbf{0}}$ & $7.26 \pm 0.01$ & $102.29 \pm 0.05$ \\
\hline $\mathbf{S}_{\mathbf{1}}$ & $7.31 \pm 0.03$ & $104.51 \pm 0.06$ \\
\hline $\mathbf{S}_{\mathbf{2}}$ & $7.28 \pm 0.03$ & $103.34 \pm 0.03$ \\
\hline $\mathbf{S}_{\mathbf{3}}$ & $7.33 \pm 0.0 .02$ & $105.60 \pm 0.03$ \\
\hline
\end{tabular}

\section{Organoleptic properties}

The data on sensory evaluation of cupcakes tabulated in Table 5 and presented in Fig. 2 indicated effect of ragi supplementation on organoleptic properties of cupcakes. The sensory score of organoleptic properties (7.3-7.8) and overall acceptability (7.5) of cupcakes 60:40 proportions of maida and ragi was found very close to the cupcakes without ragi, hence were found acceptable. 
Table 5: Organoleptic characteristics of the ragi cupcakes

\begin{tabular}{|c|c|c|c|c|c|}
\hline \multirow{2}{*}{ Sample } & \multicolumn{5}{|c|}{ Organoleptic characteristics } \\
\cline { 2 - 6 } & $\begin{array}{c}\text { Colour and } \\
\text { Appearance }\end{array}$ & Texture & Taste & Flavour & $\begin{array}{l}\text { Overall } \\
\text { Acceptability }\end{array}$ \\
\hline $\mathbf{S}_{\mathbf{0}}$ & 7.6 & 7.4 & 7.7 & 7.7 & 7.6 \\
\hline $\mathbf{S}_{\mathbf{1}}$ & 6.9 & 7.2 & 6.2 & 6.5 & 6.7 \\
\hline $\mathbf{S}_{\mathbf{2}}$ & 7.6 & 7.8 & 7.5 & 7.3 & 7.5 \\
\hline $\mathbf{S}_{\mathbf{3}}$ & 6.9 & 7.3 & 7.1 & 7.2 & 7.1 \\
\hline $\mathbf{S E}_{\mathbf{( \pm}}$ & 0.20 & 0.13 & 0.33 & 0.25 & 0.21 \\
\hline $\mathbf{C D}$ & 0.65 & 0.43 & 1.08 & 0.81 & 0.67 \\
$\mathbf{( 5 \% )}$ & & & & & \\
\hline
\end{tabular}

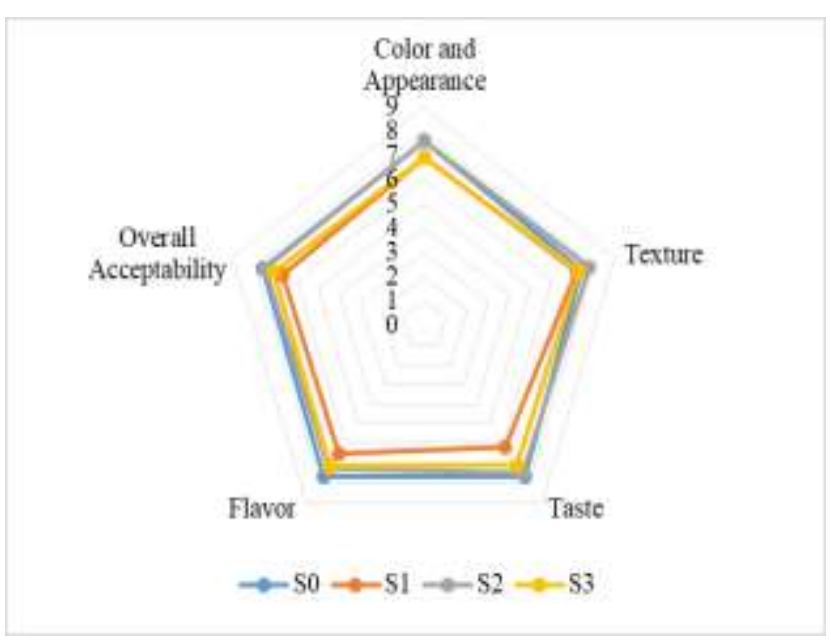

Fig.2 Organoleptic characteristics of ragi cupcakes

\section{CONCLUSION}

It is evident from ongoing discussion that ragi supplemented cupcakes can be prepared by partial replacement $(40 \%)$ of wheat flour with ragi. The organoleptic score of cupcakes with 60:40 proportions of maida and ragi was found very close to the control sample with overall acceptability of 7.5. Hence it can be concluded that $40 \%$ of wheat flour can replaced with ragi for making acceptable cupcakes rich in calcium and iron.

\section{REFERENCES}

[1] Limbachiya C. and Amin. B. (2015). Development of multigrain product muffins. International Journal of Food and Nutritional Science, 4(5):42-51

[2] Desai A. D., Kulkarni S. S., Sahoo A. K., Ranveer R.C. and Dandge P.B. (2010). Effect of Supplementation of Malted Ragi Flour on the Nutritional and Sensorial Quality Characteristics of Cake. Advance Journal of Food Science and Technology, 2(1): 67-71
[3] Chandra, D., Chandra, S., Pallavi, Sharma, A. K., (2016). Review of Finger millet (Eleusine coracana (L.) Gaertn): A powerhouse of health benefiting nutrients. Food Science and Human Wellness, 5 (2016) 149-155

[4] Goswami P., Mehra M. and Pratibh P. (2010). Studies on Proximate Composition of Ragi Based Developed Instant Mixes. Advance Journal of Food Science and Technology, 2(1):67-71

[5] Choudhary H. and Jood S. (2013). Functional and Nutritional Characteristics of Ragi-Wheat Composite Flour and Its Use in Bread Making. Asian Journal of Dairy and Food Research, 32(2): 120-125

[6] A.O.A.C. 1990. Official Methods of Analysis, Association of Official Analytical Chemists, Washington, DC, 15th edition.

[7] Ranganna S., 2007. Handbook of analysis and quality control for fruits and vegetables products, Tata Mcgraw Hill Publication, pp 1-45.

[8] Thimmaiah S. R. (2012). Standard methods of biochemical analysis, Kalyani Publications

[9] Anon (1971). Sensory Evaluation. Is6373-1971. Indian Standard Institution

[10] Goswami P., Mehra M. and Pratibh P. (2017). Studies on Proximate Composition of Ragi Based Developed Instant Mixes. International Journal of Current Microbiology and Applied Science, 6(8): 3401-3405 